\title{
STANDAARDWERK OVER BEHANDELING ALLEDAAGSE KLACHTEN
}

T.O.H. de Jongh, H. de Vries [redactie]. Therapie van alledaagse klachten. Handreiking voor rationeel symptomatisch behandelen. Houten: Bohn Stafleu van Loghum, 2018. 442 pagina's.

ISBN 978-90-368-1921-3. Prijs € 64,95 [inclusief app].

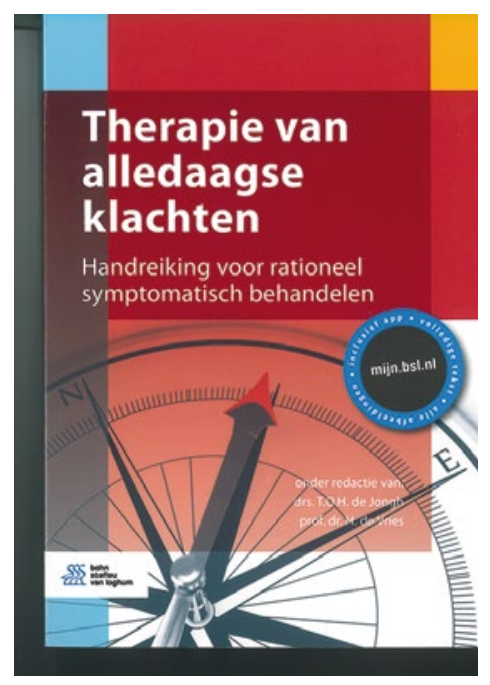

Dit heerlijk overzichtelijke leer- en naslagboek, tevens voorzien van toegangscode tot app en internetversie, biedt (huis)artsen en coassistenten bruikbare handvatten bij de behandeling van alledaagse klachten in de huisartsenpraktijk. Een aanrader!

In de eerste hoofdstukken wordt helder, maar wat té uitvoerig, toegelicht wat een symptoom- of syn-

droomdiagnose is (in tegenstelling tot een ziektediagnose) en hoe een verstoorde functie als oorzaak van een klacht kan leiden tot keuze van passend medisch en paramedisch handelen. Vervolgens behandelen de auteurs in een serie korte hoofdstukken de meest voorkomende alledaagse klachten, waarvan er enkele het afgelopen jaar in H\&W zijn gepubliceerd: van duizeligheid, urineverlies en lagerugklachten tot overmatig zweten en overspanning. De onderwerpen zijn steeds beschreven vanuit de klacht en dat zoekt plezierig. Elk hoofdstuk begint met een samenvatting. Onder het kopje 'Van klacht naar diagnose' staan de stappen om tot een symptoomdiagnose te komen en welke ziektediagnosen, waarvan de alarmsignalen duidelijk worden genoemd, moeten zijn uitgesloten. Dan volgen behandelingsmogelijkheden met toelichting en ten slotte een literatuuroverzicht. Er is steeds een standaardschema van de therapeutische mogelijkheden aanwezig en dat biedt een snel overzicht van goed en minder goed onderbouwde behandelingen. Het is mooi dat naast de sterkte van het bewijs hier niet het effect van een behandeling wordt benoemd maar de winst ervan, gedefinieerd als de voordelen (effect) van de behandeling afgewogen tegen de potentiële schade (nadelen).

Joke Schulkes-Van de Pol

WAARDERING: 